\title{
Examining the Organization of a Second Grade Classroom: An Action Research Analysis Using Human Resource and Structural Frames
}

\author{
Karen Capraro \\ Rhode Island College
}

\begin{abstract}
This paper presents an examination and analysis of the restructuring of the organization of a second grade classroom housed in a laboratory school setting. During the 2014-2015 academic year, the traditional power structure of teacher as ultimate authority with students positioned as subordinates was explored. Using action research and the application of frame theory the organizational structure of the second grade classroom is considered using human resource and structural frames.
\end{abstract}

Keywords: organization; power, elementary; structure; human resource

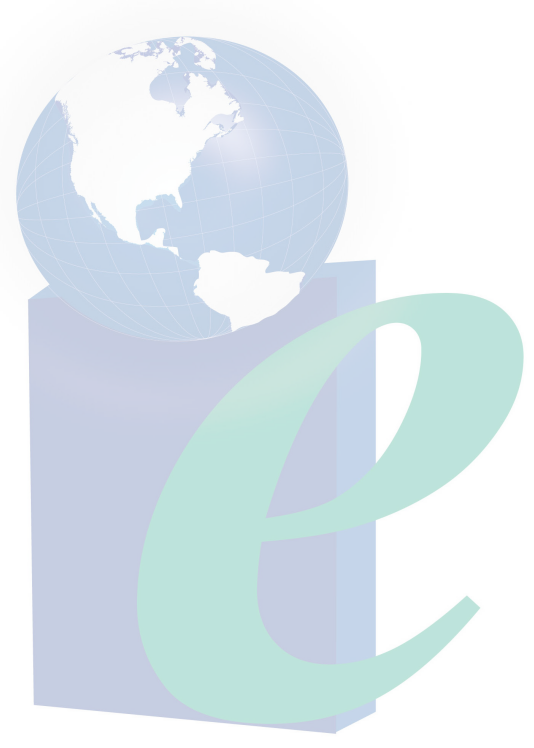




\section{Examining the Organization of a Second Grade Classroom: An Action Research Analysis Using Human Resource and Structural Frames}

I invite you, the reader, to think of a usual classroom - it can be one in which you were a member, or one derived from your imagination. Where is the teacher? What are the students doing? What does the room look and sound like? It is likely that the classroom you have roused in your mind is still. Students are working independently at their desks. The teacher is situated toward the front of the room, chalk in hand. Her head is slightly tilted, with one ear raised to capture any sound, as her eyes scan the space for disruptions-disruptions in behaviors, disruptions in understanding, disruptions to her lesson. Her aim is to teach the students something.

But what is she teaching? Let's pretend she is teaching a mathematics lesson. Numbers are scrawled across the board as she instructs her students on the standard algorithm for addition. The students diligently copy the equations, "carrying the one" when necessary. Suddenly, the bell sounds, books are gathered, metal chairs scrape against the linoleum floor as students prepare for lunch, and the room becomes empty. Satisfied that she has taught what she intended to teach, the teacher moves toward the board and erases her examples, readying herself for the following lesson. What will she teach her students next? Indeed, what will they learn?

Darling-Hammond (2006) states, "In the United States, education must [among other things] serve the purposes of a democracy. This...means that teachers assume the purpose of enabling young people to participate fully in political, civic, and economic life in our society" ( p. 303). How does our imaginary "usual" classroom support this purpose? In what ways are the students being prepared?

Dewey (1916), when discussing aims in education, wrote:

To talk about an educational aim when approximately each act of a pupil is dictated by the teacher, when the only order in the sequence of his acts is that which comes from the assignment of lessons and the giving of directions by another, is to talk nonsense. (p. 102)

His words, if they are to be considered in relation to Darling-Hammond's, suggest that our "usual" classroom structures, with teachers positioned as authorities and students as passive learners, cannot support the development of political, civic, and economic participants. How, then, might our classrooms be restructured to support this development?

In this paper, I begin to examine the organization of my own second grade classroom in an effort to answer this question. Specifically, using action research, and the application of frame theory (Bolman \& Deal, 2013), I will (a) detail the latest organizational structure of my classroom, (b) provide contrasting cases for analysis, and (c) utilize Bolman \& Deal's (2013) central question, "What do we know about organizations and leadership that is genuinely relevant and useful to practitioners and scholars?” (p. viii), in an effort to lay the groundwork for creating classrooms that support the development of active participants within a democracy.

\section{Theoretical Framework}

Kurt Lewin (1890-1947) is often accredited with inventing the term “action research" around 1934 (Mills 2003, p. 5; Tomal, 2003). For Lewin (as cited in Adelman, 1993), action research was characterized by (a) the discussion of problems by active participants, (b) group decisions on 
how to move forward, (c) routine monitoring, and (d) regular reflection. Like Lewin, BrydonMiller, Greenwood, and Maguire (2003), assert, "there are strong elements of action research in the work of John Dewey, both in his philosophical work and in his studies and experiments in education” (p. 2).

Action researchers, ascribing to the belief that knowledge is socially constructed, are committed to a form of research, "which challenges unjust and undemocratic economic, social and political systems and practices” (Brydon-Miller et al., 2003, p. 3) in favor of "an explicitly political, socially engaged, and democratic practice” (Brydon-Miller et al, 2003, p. 5). Interestingly, before educators began using action research more regularly within their work, action research was employed "within the business world by organization development consultants...concerned with improving employee morale, productivity, profitability, teamwork, communication, and quality of work life” (Tomal, 2003, p. 9).

Bolman and Deal (2013) write that it is only within the last century that social scientists began to consider organizations in terms of how they work-or do not work. In fact, social scientists have developed multiple theories, each theory with its own set of assumptions and particular view. Bolman and Deal (2013) do not espouse any particular tradition, but instead use four perspectives, or frames, "to capture the subtlety and complexity of life in organizations" (p. 14). For the purposes of this study, I will utilize two of Bolman and Deal's frames-human resource and structural-while conducting action research, to analyze the reorganization of my second grade classroom.

\section{Review of Literature}

Educators have long supported the idea that schools should strive to produce students who are responsible citizens, able to actively engage in a democracy (Cohen, 2006). Educational policies however, heavily influenced by neo-liberal and neoconservative politicians since the release of $A$ Nation at Risk in 1983 (US, National Commission on Excellence in Education), have been restructured around the belief that the aim of schools is to prepare students for the global economy (Goodlad, 2000; Hursh, 2005). These educational reforms have given rise to a system that overly stresses "individualism, competition, markets, and auditing through standardized tests and other accountability measures” (Hursh, 2005, p. 13). This overemphasis on individual, standardized test scores is, "inadvertently retarding academic achievement and preventing future generations of young people from developing the ability to be active, engaged members of a democracy” (Cohen, 2006, p. 223).

Ironically, whether we are attempting to prepare our students for the global economy or for more active engagement within a democracy, we persistently hold on to an outdated organizational approach within our schools that was intended for a much simpler, stable world (Williams, Brien, \& LeBlanc, 2012). This conventional approach, which continues to dictate the organization of schools today, is a relic, leftover from a bureaucracy attempting to meet the needs of an industrial society (Williams et al., 2012).

Interestingly, according to Lewin (1944), schools and industry are similarly concerned with "the rate of learning or production" (p. 197), and the standards for both are decided upon and vigorously maintained by the teacher or the manager, with the assumption that without forceful maintenance production will be decreased. Such a system is autocratic in nature, built on a hierarchy with the teacher or the manager assuming ultimate authority. 
If we, as teachers, aim to prepare students to become active members within a democracy, we should consider moving away from these oppressive systems. While a productive democracy will still require an organizational structure, the structure and leadership cannot be based on the principles of autocracy. "Democratic behavior cannot be learned through autocratic methods" (Lewin, 1944, p. 199); for students (or workers), democratic learning can only be realized through democratic living [emphasis added] ( Lewin, 1944).

Goodlad (2000) reminds educators that schools, while exercising "custodial care” of children throughout the school day, have the opportunity to develop "the essence of each individual self in the context of justice, fairness, responsibility, and mutual caring to which the Declaration of Independence and the Constitution speak so eloquently" (p. 5). How to do so however, including what "skills, knowledge, and dispositions are needed for children to become engaged,” has only recently become part of the larger conversation (Cohen, 2006, p. 203).

How can a teacher begin to move away from autocratic practices in an effort to help her students live within a democracy? What would reorganization look like? What obstacles might he or she face while attempting this shift within the confines of an outdated organizational structure? To explore these issues, this action-oriented, problem-solving research will be guided by the following two questions relative to school structures, democracy, and organizational theory:

1. Can a teacher and the students whom she teaches successfully, productively, and democratically share power within an individual classroom?

2. Can a teacher and the students whom she teaches successfully, productively, and democratically share power within an individual classroom, within an externally structured organization?

\section{Methodology}

\section{My Role as Researcher}

According to Lewin (1944), "autocratic as well as democratic leadership consists in playing a certain role” (p. 199). For researchers engaging in action research it is easy to slip into an autocratic role, imposing their viewpoints and programs upon others, regardless of the opinions of the others involved (Stringer, 2008). For the purposes of this research, I will attempt to lead democratically, acting as a "change agent...[and] catalyst in collecting data and then working with the group in a collaborative effort to develop actions to address the issues" (Tomal, 2003, p. 9). In keeping with the characteristics of action researchers as described by BrydonMiller et al. (2003), I will assume the role of "scholar/activist," aspiring to realize actual change with actual people, while remaining "patient,...optimistic, and [open to] a certain degree of chaos, uncertainty, and messiness” (p. 12).

\section{Participants}

The role of the leader cannot be carried through without the followers playing certain complementary roles...the democratic follower has to play a role which implies, among other points, a fair share of responsibility toward the group and a sensitivity to other peoples’ feelings. (Lewin, 1944, p. 199).

Participants playing a complementary role in this research include 22, second graders ranging from 7- to 8-years of age, enrolled in a small laboratory school located on a mid-sized 
New England college campus. Of the 22 students, 11 are male and 11 female; three males are African-American and three females are Asian. The remaining children are White.

\section{Data Sources and Collection Procedures}

Patton (2002) writes, "In action research...design and data collection tend to be more informal, the people in the situation are often directly involved in gathering the information and then studying themselves, and the results are used internally to attack specific problems” (p. 221). For the purposes of this research, three primary fieldwork strategies were utilized to collect data including observations, interviews, and journals.

Observation is a popular method for data collection in research studies when the researcher aims to collect "first-hand information regarding subjects" (Tomal, 2003, p. 28). For this particular research, the researcher assumed the role of active participant observer (Mills, 2003) while simultaneously recording field notes. Informal ethnographic interviews (Mills, 2003) were conducted with participants throughout the school year, two to three times per week, within the classroom setting. These interviews were more akin to conversations between the researcher and participants, related to the reorganization of the classroom, which included opportunities for reflection and problem solving. The researcher recorded anecdotal notes during the interview sessions, which were often utilized to scaffold subsequent conversations. Finally, I maintained an informal journal, related to my course requirements, while reading Bolman and Deal's (2013) book, Reframing organizations: Artistry, choice, \& leadership (5 ${ }^{\text {th }}$ ed.) as part of my doctoral coursework.

\section{Data Analysis}

Researchers conducting action research understand that data collected can be used as both formative data, to improve the conditions of the group, and as summative data, to formally report findings to a larger community (Mills, 2003). When analyzing data gathered as the result of action research, researchers can utilize a variety of approaches. For the purposes of this research, "significant experiences and events" (Stringer, 2008, p. 87) were used as the basis for analysis. Significant, or key experiences are selected based on their importance to the people involved (Stringer, 2008). I first identified key experiences, then utilized Bolman and Deal's (2013) human resource and structural frames to deconstruct the experiences, and finally selected one key experience as a summative case.

\section{Reconsidering Mental Models}

Bolman and Deal's (2013) statement, “When we don't know what to do, we do more of what we know" (p. 7), can often be applied to classroom teachers who organize their classrooms in ways that closely resemble their "mental models" of what a classroom should be-the classrooms of their childhoods-with teachers holding ultimate authority. "Mental models are deeply held internal images of how the world works, images that limit us to familiar ways of thinking and acting. Very often, we are not consciously aware of our mental models or the effects they have on our behavior” (Senge, as cited in Bolman \& Deal, 2013, p. 37).

Traditionally, I have structured my classroom in a way that closely resembled my own mental model of a classroom. I utilized a vertical coordination structure within my classroom with me positioned as the authority figure controlling the work and the behaviors of my students while enforcing the rules and policies. Bolman and Deal (2013) write, "Vertical coordination 
rests on top-down command and control...and is generally [a] superior [structure] if an environment is stable and tasks are well understood and predictable” (pp. 57-58), which is often the case in classrooms. In the imaginary "usual” classroom, for example, vertical coordination is utilized.

This year, however, I started reconsidering my mental model as well as the organizational design of my classroom in response to two stimuli: First, I began reading Bolman \& Deal's Reframing organizations: Artistry, choice, \& leadership ( $5^{\text {th }}$ ed.) as part of my doctoral coursework entitled "Organizational theory, leadership, and policy analysis" and second, I noticed an ability in my current students to self-regulate their behaviors. Students who are selfregulated learners are "generally characterized as being motivated and efficient managers of their own actions, environment, and behavior through monitoring and strategy use (Zimmerman \& Risemberg, 1997, as cited in Regan \& Martin, 2014, p. 164). Because of these two factors, as well as my belief in supporting the development of active political, civic, and economic participants, I endeavored to build a classroom in which authority was shared. Specifically, I wanted to put the power of the classroom into the hands of my second graders.

I told my students, "I want you to be able to run this classroom without me" and in that statement, I began establishing our classroom's "image of the future... illuminating new possibilities” for our classroom (Bolman \& Deal, 2013, p. 250). In the subsequent sections of this paper, I will outline the steps I took, along with my students, toward reorganization, and will analyze two cases using Bolman and Deal's (2013) human resource and structural frames.

\section{Reorganization}

On a particularly warm day, toward the end of September, I discussed my idea with my class of 7- and 8-year olds. "Second graders," I began, "I have been thinking about our year ahead together and I have been thinking that I don't want to be in charge of us anymore. I want you to be.” Unsurprisingly, I was met with some very confused expressions. I continued, "I want you to be able to run this class without me. And to do that, we are all going to have to work together to figure out how we can make that happen.”

Always eager to try something new, my second graders readily agreed. Over the next several weeks, we began to restructure our room. Classroom jobs such as gardener and computer expert were generated, applied for, and filled, and a classroom "economy” was created. We discussed what we wanted our room to look like and sound like and then we practiced and reflected. We came together for community meetings to discuss what was working and what was not and we attempted to find satisfactory solutions to problems. I truly listened to what the children said, and then, together, we tried to coordinate their needs with curricular requirements.

We talked about our classroom as "a home away from home," where we welcomed visitors including families, and kindergarten buddies, college students, and other teachers. And, finally, we established predictable rituals, such as Morning Meeting and Closing Circle. These rituals provided both an invitation and a closure to each day and became a forum for sharing our thoughts about school, our learning, our families, and each other. It is one of these rituals, the Morning Meeting routine, which will be used to provide contrasting snapshots of our classroom - a place where power is shared and children are active participants-as the basis for frame analysis. 


\section{Shared Power: When it Works}

Sunlight streams into the classroom. Attendance has been taken and lunch orders placed. I am seated behind my desk, laptop open, reading the daily announcements. While I read, Carol waters the large fern by the window. She carefully stands on the table in front of the fern; with watering can poised, she drips cold water over the tender foliage. Other students are reading or quietly working on little projects. Some are working in pairs, laughing at pictures in their books or sharing information about reptiles. Nathan is turning on our classroom computers. Kim and Eli are gathering up books that need to be returned to the school library. They motion to me that they will be leaving the room. I nod in assent. The classroom door opens and closes.

When Carol finishes her chore, she returns the watering can to its spot by the sink and tells Alyson, who is reading in the big, comfy chair, that it is time for Morning Meeting. Alyson closes her chapter book, heads to the compact disc player, and hits "play." The familiar strains of George Winston's (1982), Rest Your Head, fill the classroom. Kids stop their work, put their things away, push in their chairs, and head over to the carpet where they join together in a circle. I, too, put away my work and head to the carpet. Kim and Eli return from the library and join us. Many of the students hum along to the music as they make their way to the rug and find their spots.

Once we are all seated and the song is complete, Imani informs us how we will pass our morning greeting that day. "Today," she begins, "because we have been studying butterflies, we will do the butterfly greeting." The kids hook thumbs and begin waving their fingers to emulate wings as they quickly pass a "Good morning" greeting around the circle. Once finished, Isaiah stands and reads the morning message that I wrote the afternoon before. "Good morning, everyone! Today is Tuesday. We will have art today. Today's number is 56 . Who can write a number sentence, which will equal 56?” he asks. Isaiah chooses a student to come to the easel to write a number sentence. We stop to discuss what is written: $10+10+10+10+10+6$. I speak for the first time to the group. "Why does that number sentence make sense?" I ask. Several students volunteer to discuss their thinking. Isaiah then turns to the class schedule, announces what we will be doing throughout the day and the day's line leader. He returns to his spot in the circle as we all turn our attention to Isabel who announces who the first "sharer" will be that morning. It is Josiah.

Josiah stands, goes to the sharing chair, and tells us that he has just joined karate. The other students give him their full attention. Josiah tells us that he can bring friends to his next class to see if they would like to join too. "Would anyone like to come?" he asks. Several hands shoot up in the air. "Okay, okay," he says grinning, "I don’t think I can remember everybody. I am going to make a sign-up sheet and put it by the mailboxes."

Isabel says, "Our next sharer is Lucy.” Lucy exchanges places with Josiah. She shows us a coin her grandmother brought back from Russia. The class is interested. Michael shouts out, "How much is it worth?” Isabel interrupts. "Shhh...," she reminds him gently, "Remember, Michael, no shouting out. Wait to be called on.”

"We have done it," I think. "We have put the kids in charge. They could run this room without me." 


\section{A Human Resource Analysis}

The human resource frame centers on what organizations and people do to and for one another. (Bolman \& Deal, 2013, p. 113)

If we as teachers consider what the people in our imaginary "usual" classroom do to and for one another, we would likely agree that, because of how we have been taught, the teacher teaches and the students are expected to learn. The students do not "do to" or "do for"- they are "done to" and "done for." In our reorganized second grade classroom, however, students have an active role. The reorganization allowed the students to become "doers" and, as a result, the classroom organization has benefited.

How has it benefited? As an example, prior to the reorganization the students were expected to, upon arrival, enter the room and read independently until Morning Meeting. After my announcement that I wanted the students to "be in charge," several students approached me about doing alternative activities. Some wanted to write, some preferred drawing, and others wanted to interact with classroom materials such as puzzles and games. Our class held a meeting and discussed their requests; we decided to try alternative activities the next day. Although I felt the students had the ability to self-regulate, I was still apprehensive.

The following day the students rose to the occasion, entering into activities that I found surprising. One student, for example, designed miniature cutouts representing the lifecycle of a butterfly. She carefully labeled each piece — egg, larva, pupa, adult_-and shared her project with other members at her table. Another student became engrossed in a tangram puzzle book and asked if he could add other puzzles to the book that he designed. Two other students, deeply interested in history, pored over a book about the Civil War and began to make a timeline of historical figures and events. Our room had become a buzz of focused, meaningful activity.

According to Bolman and Deal (2013), one of the key assumptions of the human resource frame is that "people and organizations need each other. Organizations need ideas, energy, and talent; people need careers, salaries, and opportunities” (p. 117). Our reorganization gave the students what they needed-the opportunity to showcase their talents and ideas. And, as a result, our classroom became richer for it.

Douglas McGregor (1960, as cited in Bolman \& Deal, 2013), building on Maslow’s Hierarchy of Needs (1954), suggested that a manager's (or in this case, a teacher's) "assumptions about people tend to become self-fulfilling prophecies" (p. 123). "McGregor argued that most managers harbor 'Theory $\mathrm{X}$ ' assumptions, believing that subordinates are passive and lazy, have little ambition, prefer to be led, and resist change” (Bolman \& Deal, p. 123). McGregor (1960, as cited in Bolman \& Deal, 2013) believed that an alternative assumption, named "Theory Y," would increase an individual's self-direction. My willingness to change our classroom arrival routine demonstrated trust-I was going to trust the students to try something new, and, in turn, they were trustworthy.

Creating opportunities for creative ventures was relatively easy to do. But I wanted more for our classroom. A basic human resource principle specifies that managers empower employees (Bolman \& Deal, 2013, p. 140). How, then, could I use "Theory Y" to empower the students? How could I demonstrate my belief that they truly could run the classroom without me? The first thing I did was to discuss classroom jobs with the students. Classroom jobs are not 
unusual in elementary schools. Normally there are students who sharpen pencils, erase the board, or wash tables. This year, however, we discussed jobs that I would normally do-for example, noise monitoring. We then made up new jobs and discussed the responsibilities the jobs entailed. Students applied for the jobs and described why they thought the job was right for them. I then matched applications to job vacancies.

Traditionally, I controlled Morning Meeting. I would pass the greeting. I would announce who was sharing, and I would monitor behaviors. In our reorganized classroom, however, the students are firmly in charge. Our head of sharing, for example, will remind students who are not actively paying attention to the sharer to look forward. She will also correct someone if they speak over the sharer by gently reminding the offending student that “in our classroom, we don't interrupt.” Bolman and Deal (2013) write, "Progressive organizations give power to employees as well as invest in their development” (p. 147). The head of sharing, as well as all other "employees" within our classroom, were extensively trained in relation to their job responsibilities. Our computer expert, for example, arrived in second grade with little understanding of how to turn on a computer. Over several days, I met with him to support him as he learned how to use a touchpad, how to enter a password, and how to navigate to our classroom website. Similarly, our gardener learned how to carefully water the highest plants without falling, and how to tell when a plant was thirsty.

"Investing in people requires time and persistence to yield a payoff" (Bolman \& Deal, 2013, p. 139). In a classroom, where time is of the essence and there is much to teach and learn, one might argue that to spend so much time "training" students is educationally irresponsible. Organizations that attend to human needs, however, ultimately "benefit from a talented, motivated, loyal, and free-spirited workforce” (Bolman \& Deal, 2013, p. 140).

How has our investment in "job training” paid off? One example is Alyson, our class musician. The class musician's job is a difficult one because we use music throughout the day to transition from one activity to another. I use many different compact discs and songs, so the musician needs to know which compact disc to use, and which song, and when. Alyson's music is our signal that it is time to meet for Morning Meeting. Recently, Alyson was absent from school for six days due to illness. Until her absence, I had not realized how much we depended on her and her music to move us through our day. I kept forgetting to play our songs because it was no longer my responsibility. Our classroom organization suffered as a result. When Alyson returned, her classmates were genuinely relieved. Not surprisingly, one week after Alyson returned, I woke up ill. I telephoned my principal and, after hanging up, set about writing substitute plans. This year however, after the restructuring of our classroom organization, I noticed that I did not have much to write. Aside from the specific academic lessons, I was able to write, "The kids will lead Morning Meeting" and "The kids know what to do" and "The kids will show you where to find our emergency folder." Upon my return, my principal approached me to say the substitute teacher was impressed by the responsibility my students had shown. The substitute teacher said that the students told her what to do throughout the day. The day was smooth and problem free. The principal then praised me when she said, "That is one well-run classroom.” The thing is, they did it without me. 


\section{Shared Power: When it is a Challenge}

Sunlight streams into the classroom. The students have not yet arrived. I get my laptop and sign on to our school's attendance system. I hear a commotion in the hallway. The kids have entered the building and are waiting to come into our room. I open the door and the kids surge in advising me as to their lunch plans. Are they hot lunch? Sandwich? Salad? Isaiah enters seemingly upset about something. As I am about to ask him what has happened, a parent pokes her head into the room to inquire about a lost water bottle. It's blue, with dolphins on it. Could I please make sure it is found and brought home? "No problem," I reply. Meanwhile, there is noise coming from the closet area as kids, doubled in size due to their winter coats and oversized backpacks, charge toward the Sharing Sign-Up sheet. "You shared yesterday," Andy admonishes as Trudy grabs the sheet. “That’s not fair!” Trudy simply grins and grabs a pencil.

I am about to intervene when I see that Carol has flooded our counter with water. According to Carol, the plant "overflowed." I grab some paper towel to help her clean up the mess. As I am cleaning, I notice some activity on the rug. There is a large group of students arguing over a trading card dispute. "I didn't mean to trade that card! It was my brother's! Now I am going to get in trouble!” I head over to see if I can help the students work out a compromise. I tell Carol I will return.

On my way to the rug, Nathan informs me that he is having trouble logging on to one of our older computers. "I will be right there," I tell him. The classroom phone rings. Norah answers, "Hello?" She listens and then hands me the phone. The office is still waiting for the attendance and lunch count. "Just a second," I reply. The familiar strains of Rest Your Head fill the classroom. Is it Morning Meeting time already?

I quickly finish the attendance and take my place in the circle. We have a busy day ahead and not much time. Imani begins, "Today we will do the alphabetical order greeting. I have everyone's names here on cards. I will hang them and then we will rearrange them and then say good morning - except today I am going to throw in a twist.” She winks and then proceeds to tape 22 names to the chart on the easel. Inwardly I groan. This greeting takes F-O-R-E-V-E-R. I will never get to what I need to do! I had meant to discuss the greeting with Imani in advance but now it's too late! As we wait, Kim and Eli return from returning the books to the school library. I hadn't even noticed they had left the room! They stand on the outer edge of the circle, unsure of where to sit. I intervene and suggest they say, "excuse me,” to some of the members of the circle. They eventually find two spots but now some of the other students are complaining about being "squished."

“Look! Look! A spider!” the kids shout. “Let me see! Let me see!” Our circle has become a sprawl of children and one very frightened spider. "Let’s get him outside,” I suggest, moving to pick the arachnid up with my bare hands. As I am shooing the spider out our window, our classroom door opens. A college student enters and informs me that she is there to observe our classroom. "Oh! I am so sorry!" I respond. "I completely forgot! Make yourself comfortable!” Meanwhile, Imani is still taping names to the chart. Some of the kids in the circle are starting to get restless. The clock ticks on.

The greeting is finally passed. Isaiah stands to read the morning message. "Good morning, everyone," he mumbles incoherently. "Today is Wednesday. We will have gym." Several of the students complain, “We can’t hear you!” “Could you please speak up, Isaiah?” I 
ask. He continues to mumble as we make our way through “Today’s number.” Isaiah then turns to the class schedule, announcing what we will be doing throughout the day and naming the day's line leader. Our line leader is Harry. "Harry is absent! Harry is absent!" the children begin to chant. "I’ll lead the line! No, I will! I will!” We work out a substitute line leader.

Isaiah returns to his spot in the circle and everyone turns their attention to Isabel who is poised to announce who the first "sharer" will be that morning. My stomach is churning. There are three students signed up to share, one of whom is especially - to put it kindly-descriptive. When will I get to my reading lesson? In 10 minutes, the Interventionist will arrive to work with a small group of students! We will never be ready! Harry enters the room. "Harry is here! Harry is here! Now who will lead the line?” the children shout. Just then, the fire alarm sounds...

\section{A Structural Analysis}

Bolman and Deal (2013) ask:

If someone asked you to describe your organization-your workplace, your school, or even your family-what image would come to mind? A likely possibility is a traditional organization chart: a series of boxes and lines depicting job responsibilities and levels. The chart might be shaped roughly like a pyramid, with a small number of bosses at the top and a much larger number of employees at the bottom. (p. 41)

Where is the teacher from our imaginary "usual" classroom in relation to the pyramid? Where are her students? It is likely that the teacher is positioned just above the students-somewhere in the lower third of the pyramid. The school administration, responsible for the school's schedule, is above the teacher. At the top, perhaps, is the Superintendent, responsible for the overall structure of the school.

Pretend that the teacher in our imaginary "usual” classroom wants to change the schedule or the structure of the classroom. Would either be easily accomplished? I am fortunate to teach in a laboratory school where innovation is encouraged and celebrated but I am still in the bottom third of the pyramid, and, thus, there is a tension between the reorganization of my classroom and the structural design of my school. Specifically, I am bound to the school's schedule, which was not crafted to serve human needs, but to "achieve established goals and objectives"-one of the six assumptions that undergirds the structural frame (Bolman \& Deal, 2013, p. 45).

Schools are organized to maximize efficiency. Busses arrive and doors open promptly. The Pledge of Allegiance (or some other type of morning announcement) is broadcast over the intercom as a reminder that the day is to officially begin. Reading specialists and special education teachers and occupational therapists visit children in need, in accordance with Individual Education Plans. Art, music, and physical education are offered on specified days of the week. Lunch begins promptly and ends promptly, 30 minutes later. Visits to the bathroom are even completed according to schedule. These "rules, standards, and standard operating procedures limit individual discretion and help ensure that behavior is predictable and consistent” (Bolman \& Deal, 2013, p. 52).

Children, however, do not necessarily behave according to schedule. "Teaching objectives are knotty and amorphous... students are active agents. Which teaching strategies best yield desired results is more a matter of faith than fact” (Bolman \& Deal, 2013, p. 62). Isaiah’s 
unhappiness needed to be addressed and, although I recognized his need and wanted to speak with him, it was "arrival time," and I was unable. My failure to address his needs led to further complications during Morning Meeting. Likewise, my inattention to Carol and the arguing "traders" may have been perceived as disinterest.

My anxiety increased as the clock continued to tick. The greeting, organized by Imani, was academically appropriate and, had we had more time, would have been worthwhile to many of the students in my classroom who struggle with alphabetizing words. Likewise, the opportunity to closely observe the spider over time would have connected to our study of insects (and non-insects) and would have been potentially educative. But I knew we didn't have time.

“Like an animal's skeleton or a building's framework, structural form both enhances and constrains what an organization can accomplish” (Bolman \& Deal, 2013, p. 47). Without a division of labor and specializations and a predictable schedule how could one ensure all students had the same experiences? How could the structure "ensure that diverse efforts of individuals and units mesh"? (Bolman \& Deal, p. 45). On the other hand, without division of labor and a predictable schedule, what different experiences might be available? “Troubles arise and performance suffers from structural deficits” (Bolman \& Deal, 2013, p. 45). In the case of the current structure of many, if not most, schools, a rigid adherence to historic structural frameworks has led to what Bolman and Deal might term a "stagnant bureaucracy....an older, tradition-dominated organization with an obsolete product line” (p. 87). What might a new structure look like?

Darling-Hammond \& Bransford (2005) write, "Many analysts have noted that there is very little relationship between the organization of the typical American school and the demands of serious teaching and learning" (p. 4). And yet, I am not sure if anyone has come up with a viable alternative. Indeed, we avoid the possibilities, which seem too overwhelming to contemplate, and revert to our mental models. Dewey (1938) himself said that "it is, accordingly, a much more difficult task to work out the kinds of materials, of methods, and of social relationships that are appropriate to the new education than is the case with traditional education" (p. 29). Bolman and Deal (2013), however, console and inspire us when they state, "structure...need not be machinelike or inflexible...recent years have witnessed remarkable inventiveness in designing structures emphasizing flexibility” (Bolman \& Deal, 2013, p. 48). How, then, might our educational structure be reinvented to ensure flexibility?

\section{Conclusion}

Bolman and Deal (2013) ask, "What do we know about organizations and leadership that is genuinely relevant and useful to practitioners and scholars?” (p. viii). In an attempt to answer that question, I shared the power of my classroom with 22, 7- and 8-year olds and then analyzed two contrasting cases using human resource and structural frames. The structural frame, although intended to "reflect confidence in rationality and a faith that a suitable array of formal roles and responsibilities will minimize distracting personal static and maximize people's performance" (Bolman \& Deal, 2013, p. 45) is no longer (if it ever was) an appropriate framework for schools. Instead, because of my analysis, I advocate for a human resource approach as the more appropriate organizing structure, with the intention of enabling our students to participate more fully in our society. "The human resource frame highlights the relationship between people and organizations. Organizations need people (for their energy, effort, and talent), and people need 
organizations (for the many intrinsic and extrinsic rewards they offer), but their respective needs are not always well aligned” (Bolman \& Deal, 2013, p. 135). It is important, then, that alignment be considered in relation to both classrooms and the schools in which they are housed, and both schools and the societies in which they are held.

Until this point in this discussion, the "organization" has been limited to my classroom and the "people" as the members within it. But, if we, as teachers, begin to think of the "organization" as society, and of the "people" as including students in classrooms, we begin to see the necessity of sharing power. In other words, if, as Darling-Hammond (2006) states, "education must serve the purposes of a democracy... [with] the purpose of enabling young people to participate fully in political, civic, and economic life in our society” (p. 303), then we need to recognize our students as being able to participate.

One of the key assumptions of the human resource frame highlights the "fit" between the organization and the individual. "When the fit between individual and system is poor, one or both suffer. Individuals are exploited or exploit the organization” (Bolman \& Deal, 2013, p. 117). In our imaginary "usual" classroom, who is suffering? Who is exploited? And, more tragically, when we weigh our "usual" classroom as the "individual" and our society as the “organization,” we are forced to ask, how many will ultimately suffer or be exploited?

Numbers are scrawled across the board as she instructs her students on the standard algorithm for addition. The students diligently copy the equations, "carrying the one" when necessary. Suddenly, the bell sounds, books are gathered, metal chairs scrape against the linoleum floor as students prepare for lunch, and the room becomes empty. Satisfied that she has taught what she intended to teach, the teacher moves toward the board and erases her examples, readying herself for the following lesson. What will she teach her students next? Indeed, what will they learn?

Dewey (1916) said:

One of the weightiest problems with which the philosophy of education has to cope is the method of keeping a proper balance between...the incidental and the intentional modes of education...to avoid a split between what men consciously know because they are aware of having learned it by a specific job of learning, and what they unconsciously know because they have absorbed it in the formation of their characters by intercourse with others. (p. 9)

I believe, through the sharing of power, and the recognition of the talents and ideas my students can bring to our classroom, I am allowing my students to partake in the incidental and intentional, as "doers” rather than the "done to," as they take their first steps towards becoming active political, economic, and civic participants-capable of serving our democracy.

\section{References}

Bolman, L.G., \& Deal, T.E. (2013). Artistry, choice, and leadership: Reframing organizations $\left(5^{\text {th }}\right.$ ed.). San Francisco, CA: Jossey-Bass.

Brydon-Miller, M., Greenwood, D., \& Maguire, P. (2003). Why action research?. Action Research, 1(1), 1-19.

Cohen, J. (2006). Social, emotional, ethical, and academic education: Creating a climate for 
learning, participation in democracy, and well-being. Harvard Educational Review, 76(2), 201-237.

Darling-Hammond, L., \& Bransford, J. (with LePage, P., Hammerness, K., \& Duffy, H.). (2005). Preparing teachers for a changing world: What teachers should learn and be able to do. San Francisco, CA: Jossey-Bass.

Darling-Hammond, L. (2006). Constructing $21^{\text {st }}$ century teacher education. Journal of Teacher Education, 57(3), 300-314. doi: 10.1177/0022487105285962

Dewey, J. (1916). Democracy and education. New York, NY: The Free Press.

Dewey, J. (1938). Experience and education. New York, NY: Touchstone.

Goodlad, J. I. (2000). Education and democracy: Advancing the agenda. Phi Delta Kappan, 82(1), 86-89.

Hursh, D. (2005). Neo-liberalism, markets and accountability: Transforming education and undermining democracy in the United States and England. Policy Futures in Education, 3(1), 3-15.

Lewin, K. (1944). The dynamics of group action. Educational leadership, 1(4), 195-200.

Mills, G. E. (2003). Action research: A guide for the teacher researcher ( $2^{\text {nd }}$ ed.). Upper Saddle River, NJ: Pearson Education.

Patton, M. Q. (2002). Qualitative research and evaluation methods (3rd ed.). Thousand Oaks, CA: Sage.

Regan, K. S., \& Martin, P. J. (2014). Cultivating self-regulation for students with mild disabilities: What's up? Intervention in School and Clinic, 49(3), 164-173.

Stringer , E. (2008). Action research in education ( $2^{\text {nd }}$ ed.). Upper Saddle River, NJ: Pearson Education.

Tomal, D. R. (2003). Action research for educators. Lanham, MD: Scarecrow Press.

United States. National Commission on Excellence in Education. (1983). A nation at risk: The imperative for educational reform: A report to the Nation and the Secretary of Education, United States Department of Education. Washington, D.C.: National Commission on Excellence in Education.

Williams, R. B., Brien, K., \& LeBlanc, J. (2012). Transforming schools into learning organizations: Supports and barriers to educational reform. Canadian Journal of Educational Administration and Policy, 134, 1-32.

Winston, G. (1982). Rest your head. [Recorded by Different Fur Recording]. On December [CD]. San Francisco, CA: Windham Hill Records.

Zimmerman B. J., Risemberg R. (1997). Becoming a self-regulated writer: A social cognitive perspective. Contemporary Educational Psychology, 22, 73-101. doi:10.1006/ceps.1997.0919 